\title{
COMPLICATED MIGRAINE
}

\author{
Kadek Putri Paramita Abyuda ${ }^{1}$, Shahdevi Nandar Kurniawan ${ }^{2}$ \\ ${ }^{I}$ Medical Profession Study Program, Faculty of Medicine, Brawijaya University, Malang, Indonesia \\ ${ }^{2}$ Department of Neurology, Faculty of Medicine, Brawijaya University, Malang, Indonesia \\ Correspondence : shahdevinandar@ub.ac.id
}

\begin{abstract}
Migraine is a chronic paroxysmal neurological disease characterized by attacks of moderate or severe headache accompanied by reversible neurologic and systemic symptoms. Although not life threatening, migraine can cause disability in the productive population. Migraine sufferers generally have a family history of migraine so that migraine is considered a genetic disease. Endogenous psychological factors such as stress or fatigue are the main triggers for migraine. Migraine pathophysiology involves various parts of the brain so that migraine symptoms are complex. Management of acute migraine can be done pharmacologically and non-pharmacologically. Migraine preventive management is needed if the patient has a chronic migraine or does not respond to abortive treatment.
\end{abstract}

Keyword : Migraine, aura, prodromal, trigeminovascular system

\section{PENDAHULUAN}

Migrain adalah penyakit nyeri kepala neurovaskular yang umum terjadi dan bersifat multifaktor, berulang, herediter, dan menimbulkan disabilitas pada $15 \%$ populasi produktif. Migrain paling banyak menyerang populasi berusia 22 hingga 55 tahun1. Berdasarkan World Health Organization (WHO), migrain merupakan penyebab keenam terjadinya disabilitas secara global. Meskipun tidak mengancam nyawa, tingkat keparahan dan frekuensi serangan dapat menyebabkan disabilitas dan penurunan kualitas hidup, bahkan pada fase di mana tidak terjadi serangan2. Migrain lebih sering terjadi pada wanita dibandingkan pria, dengan rasio 3:1. Migrain umum menurun pada keluarga sehingga dapat dikategorikan sebagai penyakit genetik (1).

\section{DEFINISI}

Migrain adalah penyakit neurologis kronis paroksismal yang ditandai dengan serangan nyeri kepala sedang atau berat disertai dengan gejala neurologis dan sistemik reversibel. Gejala yang sering tampak pada migrain antara lain fotofobia, fonofobia, dan gejala gastrointestinal seperti mual dan muntah. Istilah migrain refrakter digunakan untuk mendefinisikan nyeri kepala persisten yang sulit ditangani atau tidak berespon dengan pemberian terapi standar dan/atau agresif (3).

\section{PREVALENSI}

Migrain terjadi pada $17,6 \%$ wanita dan $5,7 \%$ pria. Insiden migrain tertinggi didapatkan pada usia 15 hingga 24 tahun, dengan puncaknya pada usia 20-24 tahun pada wanita dan 15-19 tahun pada pria. Sejumlah $90 \%$ serangan pertama terjadi sebelum usia 40 tahun. Prevalensi tertinggi didapatkkan pada usia 35 hingga 45 tahun. Pada dewasa berusia 18 hingga 59 tahun, prevalensi migrain diperkirakan sejumlah 17 hingga $21 \%$ bergantung pada kriteria diagnosis yang digunakan: strict migraine $8-11 \%$ dan probable migraine $9-10 \%(2,4,5)$.

Sekitar $70 \%$ penderita migrain mengalami serangan migrain tanpa aura (common migrain) dan $20 \%$ mengalami migrain dengan aura (classical atau focal migrain). Prevalensi migrain dengan aura meningkat seiring dengan usia, terjadi pada $13 \%$ serangan migrain pada penderita berusia 18-29 tahun, $20,1 \%$ pada penderita berusia $40-49$ tahun, dan $41 \%$ penderita berusia $70 \%$ atau lebih $(2,4,5)$.

\section{ETIOLOGI DAN FAKTOR RISIKO}

Pada penderita migrain, terjadi peningkatan sensitivitas otak yang berlebihan, yaitu peningkatan sensitivitas terhadap cahaya, suara, Gerakan, penciuman, atau stimuli sensori lainnya selama periode tanpa nyeri. Hipersensitivitas ini dipercaya diinduksi oleh respon korteks dan brainstem, menyebabkan terjadinya habituasi defektif (4).

Migrain dapat dipicu oleh beberapa factor: stres emosional $(80 \%)$, hormon pada perempuan $(65 \%)$, tidak makan $(57 \%)$, cuaca $(53 \%)$, gangguan tidur $(50 \%)$, bau-bauan $(44 \%)$, nyeri leher (38\%), cahaya (38\%), alkohol (38\%), asap rokok $(36 \%)$, tidur larut $(32 \%)$, panas $(30 \%)$, makanan $(27 \%)$, olahraga (22\%), aktivitas seksual (5\%).

Article History:

Received: August 16, 2021; Accepted: August 31, 2021; Published: : September 1, 2021

Cite As:

Abyuda KPP , Kurniawak SK. Complicated migraine. Journal of Pain, Vertigo and Headache; 2021.2:28-33 
Penderita dengan aura mengalami lebih banyak pemicu dibandingkan dengan penderita tanpa aura. Menstruasi merupakan penyebab utama terjadinya migrain berulang dan persisten (4).

\section{PATOFISIOLOGI}

Migrain disebabkan oleh gangguan jaringan otak yang kompleks dengan riwayat genetik yang kuat melibatkan bagian korteks, subkorteks, dan brainstem yang mempengaruhi terjadinya nyeri dan gejala lainnya (6). Organ otak umumnya tidak dapat merasakan sensasi, namun terdapat beberapa struktur otak yang sangat sensitive terhadap nyeri, seperti duramater, bagian intracranial trigeminal, saraf vagus dan glossofaringeal, dan bagian proksimal dari pembuluh intracranial yaitu cabang basilar, vertebral, dan carotid (4). Pada Sebagian besar kasus, migrain terjadi diawali pada bagian sentral otak pada area otak yang dapat menyebabkan timbulnya gejala prodromal neurologis klasik dan aura, kemudian nyeri kepala akan terjadi setelah aktivasi dari nosiseptor meningeal pada sistem trigeminofaskular (1).

Terdapat beberapa hipotesis mengenai patofisiologi migrain. Hipotesis vaskular oleh Harold Wolff merupakan hipotesis yang berkembang dan mendominasi hingga tahun 1980an. Teori ini mengasumsikan bahwa aura pada migrain terjadi akibat hipoksemia yang diinduksi vasokonstriksi yang bersifat transien, dan nyeri kepala disebabkan oleh rebound vasodilasi yang memicu terjadinya depolarisasi mekanik neuron nosiseptif primer pada dinding vascular intra dan ekstraserebral. Teori ini kemudian dibantah setelah Olesen dkk menemukan bahwa nyeri pada migrain dengan aura terjadi pada kondisi hipoperfusi setelah terjadinya hyperperfusi pada aura. Angiografi menunjukkan adanya vasodilatasi pada arteri intra dan ekstraserebral selama serangan, spesifik pada sisi yang mengalami nyeri kepala. Tatalaksana dengan sumatriptan menyebabkan terjadinya vasokonstriksi pada pembuluh ekstraserebral (4).

Patofisiologi migrain diduga melibatkan sistem kompleks trigeminovaskular (TCC). TCC merupakan organ utama yang berperan dalam memicu terhadinya nyeri kepala pada migrain. Sistem ini terdiri nucleus caudalis trigeminal, radiks posterior segmen C1-C2 dari saraf spinal (6). Patofisiologi migrain diperkirakan melibatkan aktivasi sistem TCC melalui depolarisasi neuron pseudounipolar yang menjalar dari ganglion trigeminal yang menginervasi struktur meningeal dan vascular serebral, menyebabkan aktivasi dari neuron second-order pada nucleus caudalis trigeminal (TNC) di medulla brainstem dan radiks posterior segmen saraf spinal servikal bagian atas. Stimulasi dari neuron first-order nosiseptif trigeminal menyebabkan terjadinya aktivasi pola somatotopic pada aksis rostrocaudal brainstem. Neuron second-order pada TNC dan radiks posterior servikal diregulasi oleh nucleus raphe magnus, periaqueductal gray (PAG), trigeminal nuclei rostral, dan sistem inhibitor cortical descending, meluas hingga nuclei dorsomedial dan ventroposteromedial thalamus. Nyeri trigeminal juga dikaitkan dengan aktivasi beberapa area kortikal, yaitu area insular korteks, korteks cingulatum anterior, dan korteks somatosensory (4).
Akson perifer ganglion trigeminal melepaskan calcitonin gene-related peptide (CGRP) pada TCC (6). CGRP adalah neuropeptida yang diekspresikan pada neuron perifer dan sentral dan berperan sebagai dilatator arteriolar cerebral yang poten dan modulator sirkuit nyeri sentral dan perifer. Pada neuron second-order dan third-order, CGRP memainkan peran penting dalam regulasi mekanisme nyeri sentral. Peningkatan CGRP pada penderita migrain diduga terkait dengan penurunan mekanisme inhibitor descending, menyebabkan sensitisasi sirkuit neuronal sentral multiple, meningkatkan kerentanan terhadap migrain (6).

Thalamus merupakan jalur nosiseptif dimana input dari duramater dan area kutaneus dihantarkan melalui neuron second-order trigeminovascular. Thalamus merupakan area sentral untuk memproses dan mengintegrasikan stimuli nyeri, serta berhubungan dengan berbagai area korteks, seperti korteks somatosensory, motor, visual, auditori, olfaktori, dan limbik. Hal ini menjelaskan kompleksitas pada gejala migrain. Thalamus merupakan area pivotal dari terjadinya hipersensitivitas sensoris terhadap stimuli visual dan allodynia (6).

Hipotalamus merupakan bagian otak yang memiliki koneksi langsung dan tidak langsung terhadap thalamus, neuron trigeminovaskular, dan nuclei simpatik dan parasimpatik. Penelitian menggunakan positron emission tomography menunjukkan adanya aktivasi hipotalamik selama serangan nyeri kepala pada migrain selama 24 jam serangan dan fase iktal, disertai dengan gangguan konektivitas fungsional antara hypothalamus dan area pada brainstem (6). Pada pemeriksaan menggunakan positron emission tomography (PET), didapatkan adanya peningkatan aliran darah pada hypothalamus selama fase awal serangan migrain spontan dan selama fase premonitory ${ }^{7}$. Keterlibatan hypothalamus pada migrain menjelaskan terjadinya gejala pada awal fase iktal dan bertahan sepanjang serangan berlangsung ${ }^{6}$. Adanya gangguan pada hipotalamus menimbulkan gejala seperti perubahan mood, ngidam makanan, menguap, dan kelelahan $(1,6)$. Onset migrain diduga terkait dengan jam biologis dan ritme sirkardian yang diatur oleh hipotalamus karena terjadi secara harian, bulanan, atau menyesuaikan dengan pola musim, atau siklus menstruasi pada wanita. Gangguan fisiologi tidur-bangun sebagai pemicu terjadinya migrain memperkuat dugaan keterlibatan hypothalamus. Mekanisme dopaminergic diduga memainkan peran, menyebabkan timbulnya gejala menguap pada penderita migrain (7).

Studi dengan MRI menunjukkan adanya hubungan yang kuat antara aktivitas hipotalamus dan kortikal selama fase premonitory. Keterlibatan korteks oksipital, berupa hipereaktivitas, pada migrain menyebabkan timbulnya fenomena aura visual. Imaging menggunakan PET pada penderita migrain dengan fotofobia menunjukkan adanya hipereksitabilitas pada korteks visual. Terjadinya hipereksitabilitas pada korteks terkait dengan adanya disritmia thalamocortical. Terapi dengan TMS single-pulse dapat menekan aktivasi jalur trigemino-thalamic sehingga dapat digunakan sebagai tatalaksana migrain fase akut dan preventif (7).

Teori lain mengenai patofisiologi migrain adalah teori neurogenic, di mana migrain adalah gangguan otak yang melibatkan perubahan vascular akibat aktivitas neuronal abnormal. Cortical spreading depression (CSD) merupakan 
gelombang depolarisasi intense pada membrane neuronal dan glial dari gray matter cerebral yang menyebar sepanjang otak pada velositas lambat $(2-5 \mathrm{~mm} / \mathrm{menit})$. CSD diinduksi oleh peningkatan konsentrasi $\mathrm{K}^{+}$ekstraselular melebihi batas yang ditentukan,. Stimulasi dari reseptor glutamate subtype Nmethyl-d-aspartate dapat memicu CSD dan menimbulkan ekspansi dari gelombang depolarisasi. Mekanisme pasti CSD menyebabkan migrain belum diketahui. Akan tetapi, pada penderita migrain didapatkan nilai ambang terjadinya CSD yang lebih rendah,menyebabkaan hipereksitabilitas cerebral. Dishabituasi kortikal diduga merupakan contributor utama terjadinya deficit habituasi, sebuah respon fisiologis di mana stimulasi berulang menyebabkan penurunan amplitude respon sensori $(4,6)$.

CSD dapat memicu terjadinya nyeri kepala, seperti migrain tanpa aura, dengan memicu depolarisasi pada area otak. CSD mampu menstimulasi sistem trigeminovaskular meningeal dan memicu jalur nyeri, menyebabkan inflamasi meningeal dan ekstravasasi plasma dengan melepaskan mediator seperti glutamat, potasium, ion hidrogen, dan ATP, yang menyebar ke leptomeninges dan menstimulasi nosiseptor pial. Pelepasan mediator ini memfasilitasi pelepasan neuropeptida proinflamatori vasoaktif, di antaranya calcitonin-gene-related peptide (CGRP), neurokinin A, dan substansi P dari saraf perifer dan cabang aksonal dura melalui refleks aksonal, menginduksi terjadinya inflamasi steril sebagai respons terhadap sekresi neuropeptida pada mikrovaskulatur meningeal (4). CSD diketahui menyebabkan terjadinya gejala migrain dengan aura dengan menganggu fungsi kortikal, menyebabkan disfungsi serebrovaskular yang berkepanjangan (8).

Migrain juga dapat terjadi secara perifer. Nyeri kepala pada migrain timbul dari neuron aferen primer yang menginervasi jaringan cranial yang terstimulasi, utamanya pada meninges dan pembuluh darah besar. Stimulasi langsung dari arteri meningeal dan sinus dural pada manusia menyebabkan terjadinya sensasi yang serupa dengan nyeri kepala yang menyakitkan yang terlokalisasi pada cephalic, analog dengan terjadinya migrain. Aktivasi dari neuron parasimpatik preganglionic pada nucleus salivatory superior merupakan komponen endogen alternatif yang diduga menginduksi terjadinya inflamasi meningeal, menyebabkan pelepasan molekul proinflamasi dari neuron eferen parasimpatik dari ganglion sphenopalatine. Aktivasi aferen nosiseptif yang menginervasi arteri ekstrakranial menyebabkan terjadinya nyeri kepala berdenyut. Sumber potensial migrain lainnya terdapat pada neuron sensoris yang menginervasi struktur occipital otak, di antaranya otot leher (4).

\section{MANIFESTASI KLINIS}

Migrain merupakan penyakit siklik dengan sekuens gejala yang kompleks sepanjang serangan nyeri kepala. Pada migrain episodic, migrain terjadi dalam beberapa fase gejala: fase premonitori, fase gejala neurologis transien, fase nyeri kepala intense, dan fase postdrome. Di antara episode migrain, terdapat fase interictal, di mana penderita tidak mengalami gejala. Akan tetapi, pada fase ini penderita tetap berisiko tinggi terpengaruh oleh factor pemicu ${ }^{7}$. Pada fase premonitori, serangan migrain umumnya diawali dengan adanya gejala prodromal. Pada migrain, gejala prodromal merupakan gejala yang mendahului nyeri kepala beberapa jam sebelum onset nyeri. Gejala-gejala ini timbul diduga disebabkan oleh keterlibatan hypothalamus, brainstem, dan korteks. Gejala yang dapat muncul antara lain gejala keterlibatan hipotalamus (kelelahan, depresi, iritabel, ngidam makanan, dan menguap), gejala keterlibatan brainstem (kaku otot leher dan nyeri otot), gejala keterlibatan korteks (sensitivitas abnormal terhadap cahaya, suara, dan baubauan), dan gejala keterlibatan sistem limbik (depresi dan anhedonia). Gejala aura terjadi pada fase gejala neurologis transien. Gejala Aura adalah gejala neurologis fokal sementara $(1,7)$.

Meskipun gejala kognitif bukan merupakan salah satu simptomatologi migrain, banyak penderita migrain mengeluhkan gangguan intelektual, terutama penurunan atensj dan memori. Gejala kognitif umum terjadi pada fase premonitory dan fase nyeri, dapat bertahan hingga fase postdrome. Tingkat nyeri berat, tingkat depresi dan kecemasan yang lebih tinggi, serta kualitas tidur yang buruk dan penurunan durasi tidur terkait dengan gejala penurunan kognitif yang lebih berat. Peningkatan frekuensi dan durasi migrain terkait dengan fungsi kognitif yang lebih buruk. Penderita migrain dengan aura mengalami gangguan kognitif yang lebih prominen (8).

Pada fase nyeri kepala, terjadi aktivasi jalur trigeminothalamic ascending. Eksitabilitas saraf menyebabkan timbulnya nyeri kepala. Ketika nyeri kepala terjadi, nyeri kepala biasanya akan berdenyut, dan meningkat seiring dengan meningkatnya tekanan intracranial. Gejala seperti mual, muntah, fotofobia dan fonofobia, dapat menyertai nyeri kepala. Pada nyeri kepala berat, dapat terjadi gangguan aktivitas hingga disabilitas selama nyeri kepala berlangsung. Pada beberapa kasus, dapat terjadi allodynia dan nyeri otot $(1,7)$. Gejala nyeri ini akan menghilang saat fase postdromal, namun gejala kelelahan dan disabilitas dapat menetap (7).

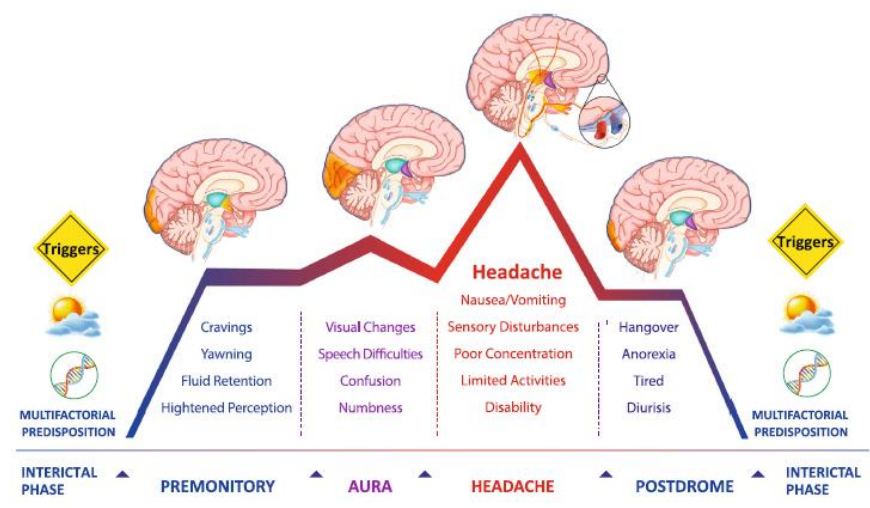

7

Gambar 1. Siklus Gejala pada Migrain

\section{PEMERIKSAAN PENUNJANG}

Pemeriksaan penunjang pada migrain tidak rutin dilakukan, kecuali penderita mengalami gejala yang tidak spesifik atau mengalami nyeri kepala mendadak, memberat kurang dari semenit (thunderclap migrain) untuk menyingkirkan diagnosis banding apabila terdapat gejala yang tidak khas. CT scan atau MRI tidak diindikasikan pada penderita migrain yang memenuhi kriteria HIS, atau untuk membedakan antara 
migrain dengan nyeri kepala lainnya. CT scan atau MRI direkomendasikan pada penderita yang menderita serangan pertama pada usia 50 tahun ke atas, penderita yang mengalami aura atipikal: onset mendadak, berlangsung lebih dari 1 jam, terjadi pada sisi yang sama berulang kali, dan/atau tanpa gejala visual, serta pada penderita dengan hasil pemeriksaan klinis abnormal. Pemeriksaan CT scan maupun MRI sebaiknya tidak dilakukan menggunakan kontras apabila terjadi nyeri kepala abnormal. Pemeriksaan EEG tidak perlu dilakukan untuk menyingkirkan nyeri kepala sekunder, pemeriksaan radiologi jauh lebih direkomendasikan (5).

\section{DIAGNOSIS}

Tabel 1. Kriteria Aura (5)

\begin{tabular}{ll}
\hline Kriteria Aura \\
\hline Setidaknya 3 dari: \\
1. $\quad$ setidaknya satu gejala aura berkembang secara bertahap \\
selama $\geq 5$ menit \\
2. minimal dua gejala aura terjadi secara berurutan & \\
3. setiap gejala aura bertahan hingga 5-60 menit & \\
4. setidaknya satu gejala aura bersifat unilateral & \\
5. setidaknya satu gejala aura positif \\
6. aura disertai, atau dalam jangka waktu 60 menit \\
$\quad$ mengalami, nyeri kepala \\
\hline
\end{tabular}

Kriteria diagnosis migrain dapat ditegakkan menggunakan kriteria yang ditentukan oleh International Headache Society (IHS) pada tahun 2013 (10).

Tabel 2. Kriteria Diagnosis Migrain (5)

Kriteria Diagnosis Migrain Tanpa Aura (ICHD-3 Beta)

A. Paling tidak 5 serangan yang memenuhi kriteria B sampai D

B. Nyeri kepala berlangsung selama 4-72 jam (baik dalam kondisi sudah diobati atau belum diobati namun belum berhasil

C. Nyeri kepala memiliki minimal dua diantara karakteristik berikut

1. Unilateral

2. Kualitas Berdenyut

3. Intensitas Sedang- Berat

4. Diperberat dengan aktivitas fisik rutin maupun tidak rutin (seperti berjalan jauh, atau naik tangga)

D. Terdapat salah satu gejala penyerta dibawah ini :

1. Mual muntah

2. Fotofobia dan fonofobia

E. Nyeri kepala tidak berkaitan dengan penyakit lain.

Kriteria Diagnosis Migrain Dengan Aura (ICHD-3 Beta)

A. Paling tidak 2 serangan yang memenuhi kriteria B dan C

B. Terdapat 1 atau lebih aura tipikal yang reversibel meliputi: aura visual, sensori, bicara, motoric, braistem.

C. Nyeri kepala memiliki minimal dua diantara 4 karakteristik berikut

1. Adanya aura yang menyebar dalam waktu $\geq 5$ menit

2. Gejala aura berlangsung 5-60 menit

3. Seridaknya 1 gejala aura bersifat unilateral

4. Aura diikiuti dengan nyeri kepala dalam watu 60 menit

D. Nyeri kepala tidak berkaitan dengan diagnosis ICHD-3 yang lain dan Transient ischemic attack telah tereklusi.

Diagnosis migrain ditentukan berdasarkan trias gejala: 1) nyeri kepala berulang tiap serangan, 2) karakteristik tipikal, 3) pemeriksaan klinis normal (5). Mnemonic POUND digunakan untuk membantu diagnosis migrain: Pulsatile (berdenyut), One-day duration (durasi 1 hari, 4-72 jam), Unilateral, Nausea atau vomiting (mual muntah), Disabling intensity (intensitas sedang-berat mengganggu aktivitas) (9).
Berdasarkan kriteria International Classification of Headache Disorders (ICHD), aura didefinisikan sebagai gejala visual, sensori, atau gejala sistem saraf pusat lain yang bersifat reversibel, dan berkembang secara bertahap pada serangan migrain. Aura dapat berupa gangguan visual, sensori, wicara dan/atau Bahasa, motor, brainstem, dan retinal. Aura tipikal berupa aura visual, sensori, wicara dan/atau Bahasa (5).

\section{DIAGNOSIS BANDING}

Diagnosis banding migrain dijabarkan pada Tabel 3.

Tabel 3. Diagnosis Banding Migrain (5)

\begin{tabular}{|c|c|}
\hline Diagnosis & Gejala \\
\hline Glaucoma akut & $\begin{array}{l}\text { Pandangan mata kabur, mual, muntah, halo, } \\
\text { kelipan cahaya }\end{array}$ \\
\hline $\begin{array}{l}\text { Benign intracranial } \\
\text { hypertension }\end{array}$ & $\begin{array}{l}\text { Onset mendadak, mual muntah, pusing, } \\
\text { pandangan kabur, papilledema, palsy saraf } \\
\text { V1 diperberat dengan batuk, mengejan, } \\
\text { perubahan posisi. }\end{array}$ \\
\hline Diseksi Karotid & $\begin{array}{l}\text { spontan atau disebabkan trauma minor atau } \\
\text { pergerakan leher mendadak, nyeri kepala } \\
\text { unilateral atau nyeri wajah, Horner } \\
\text { syndrome ipsilateral }\end{array}$ \\
\hline Cluster headache & $\begin{array}{l}\text { Tidak umum, onset mendadak, durasi menit } \\
\text { hingga jam, berulang dalam beberapa } \\
\text { minggu, dapat menghilang selama bulanan } \\
\text { atau tahunan, lakrimasi unilateral, kongesti } \\
\text { nasal, nyeri periorbital unilateral berat, } \\
\text { umum pada pria, penderita resah selama } \\
\text { episode berlangsung }\end{array}$ \\
\hline Sinusitis Frontal & $\begin{array}{l}\text { Memburuk Ketika berbaring, kongesti nasal, } \\
\text { nyeri pada sinus }\end{array}$ \\
\hline Nyeri diinduksi obat & $\begin{array}{l}\text { disebabkan terapi hormone, kontrasepsi } \\
\text { hormonal, rebound analgesic }\end{array}$ \\
\hline $\begin{array}{l}\text { Sindrome } \\
\text { postconcussion }\end{array}$ & $\begin{array}{l}\text { Trauma kepala sebelumnya, vertigo, } \\
\text { lightheadedness, gangguan konsentrasi dan } \\
\text { memori, kurangnya energi, iritabel, } \\
\text { kecemasan }\end{array}$ \\
\hline $\begin{array}{l}\text { Tension-type } \\
\text { headache }\end{array}$ & $\begin{array}{l}\text { Umum terjadi, durasi } 30 \text { menit hingga } 7 \\
\text { jam, bilateral, tidak berdenyut, intensitas } \\
\text { ringan-sedang, tidak mengganggu aktivitas, } \\
\text { tanpa mual muntah }\end{array}$ \\
\hline $\begin{array}{l}\text { Trigeminal } \\
\text { neuralgia }\end{array}$ & $\begin{array}{l}\text { Episode singkat dari nyeri tajam seperti } \\
\text { ditusuk pada distribusi saraf trigeminal }\end{array}$ \\
\hline
\end{tabular}

\section{MIGRAIN KOMPLIKATA}

Migrain komplikata adalah migrain dengan gejala neurologis fokal yang tidak termasuk dalam gejala aura saat serangan migrain. Terdapat 4 subtipe: migrain dengan aura, migrain basilar. Migrain hemiplegik, dan migrain retinal (10).

Migrain hemiplegik ditandai dengan gejala visual, sensoris, motor, afasik, dan tipe basilar yang berkembang secara bertahap dalam 20-30 menit disertai nyeri kepala. Gejala sensoris positif dan negative terjadi dalam distribusi "cheirooral". Pada Familial Hemiplegic Migrain terjadi mutasi dari ion transporter gen meliputi CACNA1A, ATP1A2, and SCN1A yang mengkode voltage gated calcium channel, pompa neuronal sodium-potassium, dan neuronal voltagegated sodium channel, yang merupakan penyebab fenotipe pada familial hemiplegic migrain phenotype. Terbagi menjadi FHM1, FHM2, and FHM3. Untuk terapi migrain hemiplegik, ketamine intranasal dan verapamil merupakan lini pertama. Profilaksis yang dapat digunakan antara lain 
verapamil, lamotrigine, sodium valproate, dan acetazolamide (10).

Migrain basilar adalah migrain yang disertai dengan disfungsi brainstem: vertigo nonposisional, diplopia, disartria, kadang dengan gangguan kesadaran ringan hingga berat. Dapat disertai dengan hypacusis, tinitus, paresthesia bilateral. Migrain basilar diduga disebabkan oleh vasospasme arteri basilar dan disfungsi ARAS. Lamotrigine dapat digunakan untuk tatalaksana migrain basilar (10).

Pada migrain retinal, terjadi gangguan visual monokular: scintillation, scotoma, kebutaan yang bersifat transien. Diduga migrain retinal disebabkan oleh vasospasme retinal sehingga obat -obatan vasokonstriktif seperti triptan dan ergot sebaiknya dihindari. Nifedipin dapat digunakan sebagai agen preventif (10).

\section{TATALAKSANA}

Terapi migrain dapat dibagi menjadi tatalaksana akut dan preventif. Tatalaksana akut migrain dapat dibagi menjadi tatalaksana spesifik dan nonspesifik. Terapi nonspesifik migrain antara lain NSAID (naproxen, ibuprofen, ketoprofen, diclofenac), asam asetilsalisilat dikombinasikan dengan metocloperamide, dan parasetamol. Terapi migrain nonspesifik dapat digunakan untuk tatalaksana migrain intensitas ringan-sedang. Kombinasi aspirin, acetaminophen, dan caffeine merupakan tatalaksana lini pertama yang efektif dan bebas dari kontraindikasi vascular seperti triptan. Aspirin dikombinasi dengan metocloperamide dapat membantu meringankan gejala gastrointestinal $(5,9)$.

Terapi spesifik migrain antara lain triptan, ergotamine, dan dihydroergotamine. Triptan merupakan antagonis reseptor serotonin 5-HT1B dan 5-HT1D dan digunakan untuk tatalaksana migrain akut. Triptan efektif untuk menangani nyeri kepala, gejala gastrointestinal, fotofobia dan fonofobia $(5,6,9)$.

Beberapa obat baru dikembangkan untuk tatalaksana migrain akut. Antagonis reseptor CGRP, gepants, memiliki efek samping sistem saraf pusat dan vascular yang lebih ringan dibandingkan dengan triptan dan berisiko lebih rendah mengalami overuse. Ditans, antagonis reseptor 5-HT1F, menghambat aktivasi sel nucleus caudalis trigeminal oleh stimulasi trigeminal. Penelitian RCT terhadap obat-obatan antagonis reseptor NMDA, ketamine, dapat pula ditargetkan sebagai target tatalaksana migrain dengan aura karena efeknya yang menurunkan tingkat keparahan aura (6).

Terapi profilaksis dapat bermanfaat bagi penderita migrain dengan indikasi migrain kronik, adanya kontraindikasi atau intoleransi terhadap terapi abortif, nyeri kepala terjadi lebih dari dua hari per minggu atau yang menghambat kualitas hidup secara berat meskipun terapi abortif telah diberikan, adanya gejala migrain yang tidak umum (hemiplegik, aura yang berkepanjangan, migrain basilar, atau infark yang bersifat migrainous). Untuk preventif, obat-obatan seperti beta bloker, antikonvulsan, antidepresan, dan modulator kanal kalsium terbukti efektif untuk mencegah terjadinya migrain $(6,9)$.

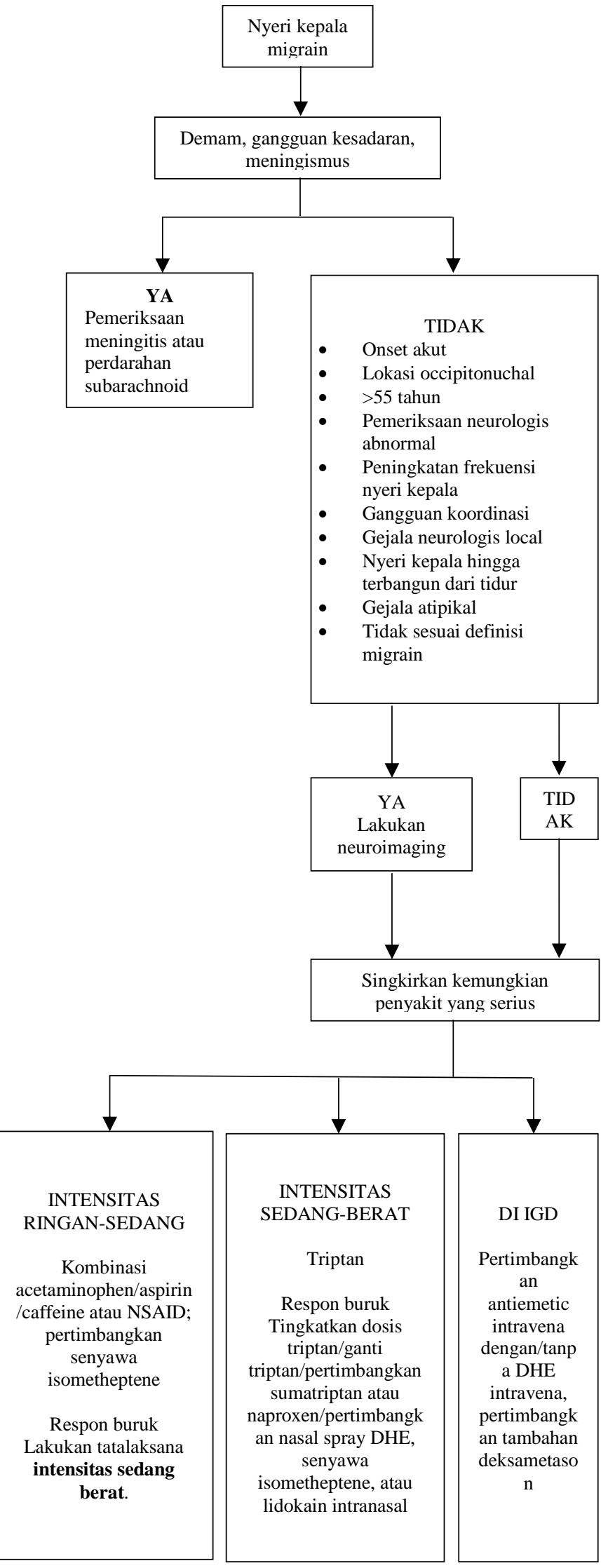

Gambar 2. Algoritma Tatalaksana Migrain (5). 
Selain farmakologis, tatalaksana nonfarmakologis juga dapat dilakukan untuk mengurangi gejala migrain dan sebagai prevensi terjadinya migrain. Neuromodulasi merupakan salah satu pendekatan yang popular sebagai tatalaksana abortif sekaligus preventif migrain. Berbagai Teknik neuromodulasi dapat dilakukan, diantaranya pendekatan invasive seperti stimulasi saraf occipital (ONS) dan stimulasi ganglion sphenopalatine (SPG) yang popular digunakan pada penderita migrain intractable, dan pendekatan noninvasif yang menargetkan transkutan, misalnya TMS, stimulasi saraf vagus noninvasif (nVNS), stimulasi saraf supraorbital, dan transcranial direct current stimulation (tDCS) (9).

Modifikasi gaya hidup dapat dilakukan untuk memodifikasi pemicu terjadinya migrain pada penderita sehingga tingkat keparahan dan dan frekuensi timbulnya gejala. Modifikasi gaya hidup dapat dilakukan sesuai mnemonic SEEDS (sleep, exercise, eat, diary, dan stress). Optimalisasi sleep hygiene dan screening untuk sleep apnea sebaiknya dilakukan, terutama apabila penderita mengalami nyeri kepala kronik tiap bangun tidur. Sleep hygiene dan modifikasi pola tidur dapat mengubah migrain kronik menjadi migrain episodic (11).

Olahraga disarankan untuk tatalaksana profilaksis migrain. Pada penderita migrain, kadar beta-endorfin pada cairan serebrospinal menurun. Olahraga dapat meningkatkan kadar endorphin dan menurunkan durasi serta frekuensi nyeri kepala (11).

Pada penderita dengan migrain, tidak ada restriksi makanan tertentu yang disarankan. Penderita migrain disarankan untuk mengonsumsi makanan secara rutin, karena penderita cenderung mengalami migrain setelah berpuasa. Cognitive behavioral therapy, mindfulness, biofeedback, dan Teknik relaksasi dapat dipelajari untuk menangani stress pada migrain (11).

\section{KOMPLIKASI MIGRAIN}

Komplikasi pada migrain meliputi status migrainosus, persistent aura without infarction, migrainous infarction, and migrain aura-triggered seizure

Menurut ICHD-II Migrain triggered seizures (Migralepsi) "menunjukkan kejang epilepsi yang terjadi selama atau dalam satu jam setelah migrain dengan aura". Migralepsi merupakan gabungan dari gejala yang ditemui pada epilepsi dan migrain. Kasus ini lebih sering pada anak-anak dibandingkan pada orang dewasa (12).

Gejala mirip migrain muncul pada awal dengan ciri-ciri migrain oftalmikus disertai mual dan muntah, diikuti dengan gejala-karakteristik epilepsi, yaitu gangguan atau kehilangan kesadaran dan diikuti (12).

\section{KESIMPULAN}

Migrain merupakan penyakit yang umum terjadi pada masyarakat dan dapat menyebabkan disabilitas. Migrain dikatakan bersifat genetik karena sering didapatkan Riwayat keluhan migrain pada keluarga. Faktor psikologis seperti stress dan gangguan tidur merupakan pemicu terjadinya migrain yang paling sering dilaporkan. Tatalaksana migrain dapat menggunakan tatalaksana nonspesifik dan spesifik, bergantung pada intensitas keparahannya. Pada migrain berulang atau tidak membaik dengan tatalaksana abortif, sebaiknya diberikan tatalaksana preventif dan nonfarmakologis. Pemeriksaan penunjang dibutuhkan untuk kasus migrain atypical. Perubahan gaya hidup dapat mengurangi pemicu migrain sehingga dapat menurunkan frekuensi dan durasi terjadinya migrain, dan meningkatkan kualitas hidup.

\section{DAFTAR PUSTAKA}

1. Burstein R, Noseda R, Borsook D. Migrain: Multiple processes, complex pathophysiology. J Neurosci; 2015. 35(17):6619-29.

DOI: 10.1523/JNEUROSCI.0373-15.2015

2. MacGregor EA. Diagnosing migrain. J Fam Plan Reprod Health Care; 2016. 42(4):280-6.

DOI: $10.1136 /$ jfprhc-2015-101193

3. D'Antona L, Matharu M. Identifying and managing refractory migrain: Barriers and opportunities? J Headache Pain; 2019. 20(1). DOI: 10.1186/s10194-0191040-x

4. Qubty W, Patniyot I. Migrain Pathophysiology. Pediatr Neurol; 2020;107:1-6.

DOI: 10.1016/j.pediatrneurol.2019.12.014

5. Lanteri-Minet M, Valade D, Geraud G, Lucas C, Donnet A. Revised French guidelines for the diagnosis and management of migrain in adults and children. $\mathbf{J}$ Headache Pain; 2014. 15(1):14-29.

DOI: $10.1186 / 1129-2377-15-2$

6. Puledda F, Messina R, Goadsby PJ. An update on migrain: Current understanding and future directions. J Neurol; 2017. 264(9):2031-9.

DOI: $10.1007 / \mathrm{s} 00415-017-8434-y$

7. Andreou AP, Edvinsson L. Mechanisms of migrain as a chronic evolutive condition. J Headache Pain; 2019. 20(1). DOI: 10.1186/s10194-019-1066-0

8. Vuralli D, Ayata C, Bolay H. Cognitive dysfunction and migrain. J Headache Pain; 2018. 19(1).

DOI: 10.1186/s10194-018-0933-4

9. Gilmore B, Michael M. Treatment of acute migrain headache. Am Fam Physician; 2011. 83(3):271-80. Avalaible from: https://www.aafp.org/afp/2011/0201/p271.html

10. Green MW, Colman R. Complicated Migrain. Headache Migrain Biol Manag; 2015. 51-60.

11. Robblee J, Starling AJ. SEEDS for success: Lifestyle management in migrain. Cleve Clin J Med; 2019. 86(11):741-9. DOI: 10.3949/ccjm.86a.19009

12. Davies PTG, Panayiotopoulos CP. Migrain triggered seizures and epilepsy triggered headache and migrain attacks: A need for re-assessment. J Headache Pain; 2011. 12(3):287-8. DOI: 10.1007/s10194-011-0344-2 